\title{
Hubungan Antara Culture Shock Dengan Hasil Belajar Mahasiswa Tahun Pertama
}

\author{
Zuni Mitasari \\ Universitas Tribhuwana Tunggadewi, Indonesia \\ Email: zmitasari@gmail.com \\ Yuswa Istikomayanti \\ Universitas Tribhuwana Tunggadewi, Indonesia \\ Email: yuswa2710@gmail.com
}

(Diterima: 31-Oktober-2017; di revisi: 09-Mei-2018; dipublikasikan: 29-Desember-2018)

\begin{abstract}
Abstrack: Adjustment to the new environment occurs both internally and externally, so students who can make adjustments gradually will be able to avoid the impact of psychological culture shock. The purpose of this research is to analyze the relationship of culture shock and adjustment to the first year student learning outcomes at Tribhuwana Tunggadewi University. This type of research is quantitative descriptive research with correlational study to determine whether there is a relationship between culture shock and student learning outcomes. Instrument of research data used is questionnaire to test culture shock with four likert scale answer option. Statistical test data obtained $r=-0,217$ and probability value (Sig. 2-tailed) $=0,054$. The conclusion, negative correlation with probability value $>0,05$ then there is no relation between culture shock with student learning outcomes.
\end{abstract}

Keyword: Culture Shock, Learning Outcome, Student, UNITRI

\begin{abstract}
Abstrak: Penyesuaian diri terhadap lingkungan baru terjadi baik secara internal maupun eksternal, sehingga mahasiswa yang dapat melakukan penyesuaian diri secara bertahap akan dapat terhindar dari dampak culture shock secara psikologis. Tujuan penelitian ini adalah menganalisa hubungan culture shock dan penyesuaian diri terhadap hasil belajar mahasiswa tahun pertama di Universitas Tribhuwana Tunggadewi. Jenis penelitian ini adalah penelitian deskriptif kuantitatif dengan studi korelasional untuk menentukan ada tidaknya hubungan antara culture shock dengan hasil belajar mahasiswa. Instrumen data penelitian yang digunakan adalah angket untuk uji culture shock dengan empat pilihan jawaban skala likert. Data uji statistik diperoleh nilai $r$ sebesar $-0,217$ dan nilai probabilitas (Sig. 2-tailed) $=0,054$. Dengan demikian dapat disimpulkan terdapat hubungan negatif dengan nilai probabilitas $>0,05$ maka tidak ada hubungan antara culture shock dengan hasil belajar mahasiswa.
\end{abstract}

Kata kunci: Culture Shock; Hasil Belajar; Mahasiswa; UNITRI

Copyright $(9) 2018$ Universitas Negeri Makassar. This is an open access article under the CC BY-NC-ND license (http://creativecommons.org/licenses/by-nc-nd/4.0/).

\section{PENDAHULUAN}

Pendidikan merupakan sebuah usaha sadar

dan terencana dengan tujuan untuk

mewujudkan suasana belajar dan kegiatan pembelajaran sehingga peserta didik secara aktif dapat mengembangkan potensi diri agar 


\section{6 | Jurnal Psikologi Pendidikan \& Konseling Vol. 4 No. 2 Desember 2018}

memiliki kekuatan spiritual keagamaan, pengendalian diri, kecerdasan, kepribadian, akhlak mulia, dan mempunyai keterampilan yang berguna bagi dirinya sendiri, masyarakat, bangsa, maupun negara (UUD No 20 Tahun 2003). Pendidikan di perguruan tinggi menuntut mahasiswa untuk berperan aktif dan selalu berinisiatif dalam proses pembelajaran, selain itu mahasiswa juga dituntut untuk belajar secara mandiri.

Menempuh perkuliahan di jenjang pendidikan tinggi merupakan periode yang penuh dengan stres karena banyak sekali tekanan sehingga sering disebut sebagai terrible phase (Gayatri, 2007). Hal tersebut dikarenakan mahasiswa akan menghadapi berbagai macam persoalan dalam periode transisi memasuki perguruan tinggi. Permasalahan tersebut diantaranya tekanan akademik, permasalahan finansial, rasa kesepian, konflik antar pribadi, serta kesulitan menghadapi perubahan dan permasalahan pengembangan diri (Gajdzik, 2005).

Mahasiswa yang melanjutkan kuliah di kota besar, seperti Malang sebagian besar merupakan mahasiswa perantau dari berbagai daerah di Indonesia dengan berlatar belakang budaya yang berbeda-beda. Mahasiswa baru yang berada pada tahun pertama akan mengalami culture shock di daerah dimana ia melanjutkan pendidikan di perguruan tinggi. Hal tersebut dikarenakan keadaan lingkungan yang berbeda jauh dengan daerah asalnya. Culture shock adalah keadaan yang dapat menyebabkan kebingungan terhadap lingkungan dengan budaya yang baru sehingga dapat memicu timbulnya emosi negatif (Hutapea, 2014). Culture shock ini akan sangat terasa dialami oleh mahasiswa perantauan yang berasal dari pulau yang berbeda.

Universitas Tribhuwana Tunggadewi (UNITRI) merupakan salah satu perguruan tinggi swasta yang berada di Kota Malang. Kampus ini memiliki mahasiswa yang sangat beragam baik ditinjau dari asal daerah, agama, suku, bahasa, dan budaya sehingga tidak salah jika kampus ini disebut sebagai kampus multikultural. Sehubungan dengan hal tersebut, maka pada awal tahun masuk ajaran baru ada banyak mahasiswa baru yang datang dari berbagai daerah di Indonesia, terutama berasal dari Indonesia timur. Mahasiswa UNITRI diantaranya berasal dari Kalimantan Barat, Kalimantan Timur, Kalimantan Utara, Nusa Tenggara Timur, Maluku, Papua bahkan dari negara tetangga, yaitu Timor Leste. Pendidikan yang diselenggarakan di kampus multikultural pastinya berbeda dengan kampus pada umumnya karena mahasiswa yang sangat heterogen ditinjau dari suku, agama, bahasa, budaya, dan adat istiadat. Pendidikan multikultural diartikan sebagai pendidikan tentang keragaman kebudayaan dalam upaya untuk merespon perubahan demografis dan kultural lingkungan masyarakat tertentu bahkan dunia secara keseluruhan (Arifudin, 2007).

Berdasarkan hasil observasi dan survei pada bulan April 2016 terhadap mahasiswa UNITRI semester dua maka didapatkan informasi bahwa mahasiswa pada tahun pertama mengalami beberapa permasalahan, yaitu 1) mahasiswa mengalami kesulitan dalam berkomunikasi dengan teman kuliah, seperti dari segi bahasa, banyak mahasiswa yang memiliki logat yang bermacam-macam dan ada beberapa bahasa yang terkesan berlogat kasar, 2) mahasiswa harus beradaptasi dengan lingkungan sekitar karena karena warga Malang cenderung lebih sopan, bahasanya halus, dan sopan, 3) mahasiswa yang sulit melakukan penyesuaian diri mengaku kesulitan mendapatkan teman, 4) sebagian besar mahasiswa berlatar belakang ekonomi kurang mampu sehingga terkendala dengan kiriman uang yang terlambat sehingga mereka harus pandai mengatur keuangan mereka, dan 5) mahasiswa dari luar jawa mengaku kebutuhan sehari-hari di pulau Jawa khususnya di Kota Malang sangat terjangkau berbeda sekali dengan harga di daerah asal meraka. Secara umum pada tahun pertama kuliah mereka masih merasa kesulitan dalam penyesuaian diri terhadap lingkungan sekitar. Meskipun demikian, mereka terus berusaha untuk menyesuaikan diri dengan cara memahami tradisi baru yang ada di sekitar mereka.

Saat memasuki suatu budaya yang dianggap asing maka mahasiswa akan beradaptasi terhadap cara hidup yang baru dan harus mempelajari hal-hal baru yang ada pada dirinya. Berkaitan dengan hal tersebut maka mahasiswa tersebut akan melakukan penyesuaian diri agar dapat bersikap adaptif terhadap lingkungan sosial dimana ia tinggal (Hutapea, 2014). Penyesuaian diri ini terjadi baik secara internal maupun eksternal, sehingga mahasiswa yang dapat melakukan penyesuaian diri ini secara bertahap akan dapat terhindar dari dampak culture shock secara psikologis. Kesulitan penyesuaian diri yang dialami oleh 
mahasiswa ini dapat berdampak dalam berbagai hal terkait dengan kegiatan belajar. Kunci keberhasilan dari suatu proses belajar adalah penyesuaian (Novera, 2004).

Penelitian ini penting untuk dilaksanakan karena belum ada penelitian tentang pendidikan khususnya tentang psikologi pendidikan di UNITRI. Adanya penelitian pendahuluan tentang korelasi culture shock dan penyesuaian diri terhadap hasil belajar ini kedepannya diharapkan dapat menjadi dasar bagi penelitian-penelitian pendidikan yang lain di UNITRI.

Identifikasi faktor-faktor penyebab tinggi rendahnya hasil belajar di suatu perguruan tinggi penting untuk dilaksanakan karena digunakan sebagai bahan evaluasi institusi dalam perbaikan sistem pembelajaran. Hal ini penting karena berkaitan erat dengan kompetensi lulusan perguruan tinggi tersebut. Selain itu, hasil dari penelitian ini juga diharapkan dapat memberikan sumbangsih dalam perbaikan kurikulum untuk pendidikan Indonesia yang lebih baik.

Tujuan penelitian ini adalah Menganalisa hubungan culture shock dan penyesuaian diri terhadap hasil belajar mahasiswa tahun pertama di Universitas Tribhuwana Tunggadewi.

\section{METODE}

Jenis penelitian ini adalah penelitian deskriptif dengan pendekatan kuantitatif. Desain penelitian ini yaitu studi korelasional untuk menentukan ada tidaknya hubungan dua variabel atau lebih dan sejauh mana keterkaitan antar variabel-variabel tersebut. Penelitian ini dilaksanakan di kampus multikultural Universitas Tribhuwana Tunggadewi (UNITRI) Malang. Populasi dalam penelitian ini adalah mahasiswa UNITRI sedangkan sampel penelitian berjumlah 79 orang mahasiswa UNITRI. Metode penentuan sampel yaitu purposive sampling, dengan teknik pengambilan sampel aksidental.

Survei penelitian dilakukan terhadap mahasiswa yang memiliki syarat-syarat responden penelitian, yaitu 1) mahasiswa UNITRI yang berasal dari luar kota Malang, 2) belum pernah tinggal menetap di kota Malang sebelumnya, 3) sedang menjadi mahasiswa untuk program studi di UNITRI dengan lama studi minimal 1 semester dan berada pada tahun pertama perkuliahan (semester awal), dan 4) tidak memiliki keluarga yang tinggal menetap di kota Malang.

Data culture shock diukur dengan memodifikasi skala pada indeks stres kehidupan yang terdiri atas lima dimensi kehidupan, yaitu 1) masalah finansial, 2) kesulitan bahasa, 3) masalah deskriminasi, 4) permasalahan kultural, dan 5) tekanan akademik. Alternatif jawaban menggunakan model skala Likert dengan empat alternatif pilihan dari pilihan "sangat jarang" (nilai 1) sampai "sangat sering" (nilai 4). Data penyesuaian diri diukur melalui skala penyesuaian diri dengan memodifikasi skala penyesuaian diri (Hutapea, 2014). Alternatif jawaban menggunakan model skala Likert dengan empat alternatif pilihan jawaban dari pilihan "sangat buruk" (nilai 1) sampai "sangat baik" (nilai 4) untuk item favorable dan nilai sebaliknya untuk item unfavorable.

Data culture shock, penyesuaian diri, dan hasil belajar yang diperoleh selanjutnya dianalisis statistik dengan analisis korelasi pearson untuk menguji keterkaitan variabel bebas (shock culture) dan variabel terikat (hasil belajar mahasiswa). Hasil analisis data dikatakan signifikan jika nilai $\mathrm{r} \leq 0,05$, sangat signifikan $(\mathrm{r}=0,01)$, dan tidak signifikan $(\mathrm{r}>$ $0,05)$.

\section{HASIL DAN PEMBAHASAN}

Aspek pengamatan dalam item angket culture shock meliputi empat hal, yaitu 1) Kemampuan adaptasi mahasiswa (8 item), 2) Faktor yang mempengaruhi cepat lambatnya proses adaptasi (18 item), 3) Bentuk culture shock yang dialami oleh mahasiswa (22 item), dan 4) Upaya mengatasi pengaruh culture shock terhadap hasil belajar (7 item). Masing-masing aspek pengamatan tersebut dijabarkan ke dalam 34 item pernyataan favourable dan 21 item pernyataan unfavourable. Data asal daerah dan agama mahasiswa responden secara berurutan disajikan pada Diagram 1 dan 2. 

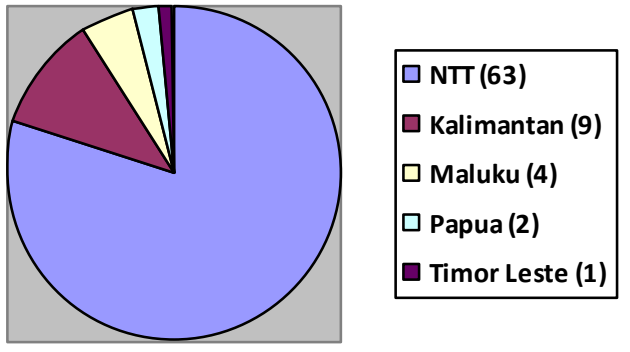

Diagram 1. Jumlah Data Responden Penelitian berdasarkan Asal daerah
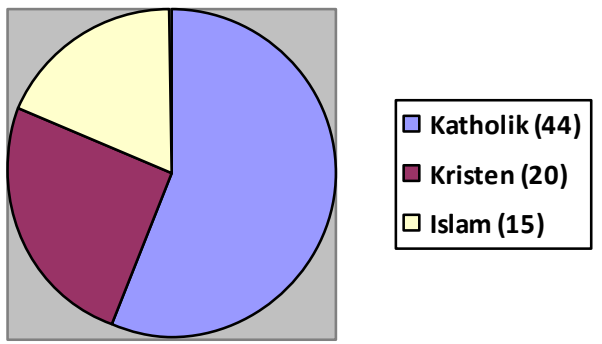

Diagram 2. Jumlah Data Responden Penelitian berdasarkan Agama yang Dianut

Berdasarkan hasil analisis data yang diperoleh diketahui bahwa rata-rata kondisi culture shock yang dialami oleh mahasiswa yaitu sebesar $60 \%$ (kategori tinggi) dan faktorfaktor yang menyebabkannya sebesar $48 \%$ (kategori sedang) meskipun demikian kemampuan adaptasi mahasiswa juga tergolong tinggi yaitu sebesar $51 \%$. Kemampuan adaptasi mahasiswa dipengaruhi oleh beberapa faktor yang mempengaruhi cepat lambatnya proses adaptasi dengan persentase sebesar 54\% (kategori tinggi). Kriteria kemampuan adaptasi mahasiswa dijabarkan pada Tabel 1.

Tabel 1. Kualifikasi Kemampuan Adaptasi Mahasiswa

\begin{tabular}{cll}
\multicolumn{3}{c}{ Mahasiswa } \\
\hline No & \multicolumn{1}{c}{ Kriteria } & \multicolumn{1}{c}{ Interval } \\
\hline 1 & Sangat Tinggi & $76 \%-100 \%$ \\
2 & Tinggi & $51 \%-75 \%$ \\
3 & Sedang & $26 \%-50 \%$ \\
4 & Rendah & $0 \%-25 \%$ \\
\hline
\end{tabular}

Dikutip dari Kholivah (2009)

Berikut ini adalah penjabaran mengenai kondisi culture shock yang dialami oleh mahasiswa tahun pertama di kampus multicultural dan pola penyesuaian diri mahasiswa.
1. Kondisi Culture Shock yang Dialami oleh Mahasiswa Tahun Pertama di Kampus Multikultural

Berikut ini data persentase berbagai bentuk Culture Shock yang dialami oleh Mahasiswa (Tabel 2).

Tabel 2. Bentuk Culture Shock yang Dialami oleh Mahasiswa

\begin{tabular}{|c|c|c|}
\hline No & Pernyataan & $\begin{array}{l}\text { Persent } \\
\text { ase }(\%)\end{array}$ \\
\hline 1 & $\begin{array}{l}\text { Saya merasa tegang saat } \\
\text { memasuki wilayah yang } \\
\text { berbeda dengan budaya saya }\end{array}$ & 60 \\
\hline 2 & $\begin{array}{l}\text { Saya merasa asing dan sendiri } \\
\text { berada di lingkungan saya yang } \\
\text { baru ini }\end{array}$ & 53 \\
\hline 3 & $\begin{array}{l}\text { Sering merasa tidak dihargai } \\
\text { oleh orang di lingkungan baru. }\end{array}$ & 54 \\
\hline 4 & $\begin{array}{l}\text { Saya merasa menjadi lebih } \\
\text { sentimen/tersinggung apabila } \\
\text { ada yang menyinggung budaya } \\
\text { saya }\end{array}$ & 72 \\
\hline 5 & $\begin{array}{l}\text { Saya selalu sedih / menangis } \\
\text { karena jauh dari keluarga }\end{array}$ & 66 \\
\hline 6 & $\begin{array}{l}\text { Saya sangat ingin pulang ke } \\
\text { rumah dan bertemu keluarga } \\
\text { dan teman-teman saya di rumah } \\
\text { (Homesickness) }\end{array}$ & 76 \\
\hline 7 & $\begin{array}{l}\text { Saya merasa tidak diterima oleh } \\
\text { orang-orang lokal di budaya } \\
\text { yang baru ini }\end{array}$ & 52 \\
\hline 8 & $\begin{array}{l}\text { Saya merasa kehilangan orang- } \\
\text { orang yang telah saya kenal } \\
\text { sebelumnya }\end{array}$ & 63 \\
\hline 9 & $\begin{array}{l}\text { Saya marah, benci, dan enggan } \\
\text { untuk berinteraksi dengan } \\
\text { orang-orang yang ada di } \\
\text { lingkungan baru saya }\end{array}$ & 48 \\
\hline 10 & $\begin{array}{l}\text { Saya memandang budaya asli } \\
\text { saya sebelumnya masih lebih } \\
\text { baik daripada budaya baru yang } \\
\text { saya hadapi sekarang }\end{array}$ & 60 \\
\hline 11 & $\begin{array}{l}\text { Saya merasa telah kehilangan } \\
\text { jati diri selama berada di } \\
\text { lingkungan baru ini }\end{array}$ & 55 \\
\hline 12 & $\begin{array}{l}\text { Orang- orang di lingkungan } \\
\text { baru membentuk suatu stereotip } \\
\text { (pandangan negatif) terhadap } \\
\text { nilai-nilai budaya saya }\end{array}$ & 59 \\
\hline 13 & $\begin{array}{l}\text { Saya merasa takut akan } \\
\text { keamanan diri karena } \\
\text { perbedaan latar belakang } \\
\text { budaya }\end{array}$ & 62 \\
\hline
\end{tabular}


buruk tentang budaya baru saya sekarang bila bersama dengan orang-orang dalam kelompok budaya saya

15 Saya merasa tertekan setelah saya pindah ke Malang

16 Saya merasa sedih berada di lingkungan yang tidak familiar

17 Sangat menyakitkan bagi saya karena orang-orang disini tidak mengerti nilai-nilai budaya saya

18 Saya merasa minder karena latar belakang budaya saya

19 Saya pernah merasa sakit atau nyeri yang tidak saya tahu sebabnya selama beradaptasi di tempat yang baru

20 Saya pernah mengalami alergi (flu tiap bangun pagi atau kembung/mual) selama berada di lingkungan baru ini, yang sebelumnya saya tidak pernah mengalaminya

21 Saya mempunyai masalah dengan pola tidur saya semenjak saya memasuki daerah yang masih asing ini

22 Saya mempunyai masalah dengan pola makan selama beradaptasi di lingkungan baru ini (nafsu makan berkurang/ bertambah karena stres)

\section{Rata-rata}

\section{Pola Penyesuaian Diri Mahasiswa}

Berikut ini data persentase berbagai upaya untuk mengatasi terjadinya Culture Shock yang dialami oleh Mahasiswa (Tabel 3), kemampuan adaptasi mahasiswa (Tabel 4), dan faktor-faktor yang mempengaruhi cepat lambatnya proses adaptasi mahasiswa (Tabel 5).

\section{Tabel 3. Upaya Mengatasi Culture Shock terhadap Hasil Belajar Mahasiswa}

\begin{tabular}{clc}
\hline No & \multicolumn{1}{c}{ Pernyataan } & $\begin{array}{c}\text { Persentase } \\
(\%)\end{array}$ \\
\hline 1 & $\begin{array}{l}\text { Aktif menjalin komunikasi } \\
\text { dan berelasi dengan teman- } \\
\text { teman baik dari dalam } \\
\text { maupun luar kampus. }\end{array}$ & 84 \\
\hline 2 & $\begin{array}{l}\text { Aktif dalam kelompok } \\
\text { belajar di luar kampus. } \\
\text { Aktif dalam melibatkan diri } \\
\text { di dalam kelas misalnya }\end{array}$ & 37 \\
\end{tabular}

mengemukakan pertanyaan

dan pendapat.

4 Rajin mengunjungi

perpustakaan atau browsing internet untuk mencari referensi, modul atau buku yang relevan dengan mata kuliah yang responden tempuh.

5 Responden selalu membiasakan diri untuk mempelajari dan membaca materi yang akan disampaikan oleh dosen.

6 Responden terbuka dalam menerima pikiran yang berbeda dengan pikirannya .

7 Saya mampu mengatur waktu dengan baik.

\section{Rata-rata}

Tabel 4. Kemampuan Adaptasi Mahasiswa

\begin{tabular}{clc}
\hline No & \multicolumn{1}{c}{ Pernyataan } & $\begin{array}{c}\text { Persentase } \\
(\mathbf{\%})\end{array}$ \\
\hline 1 & $\begin{array}{l}\text { Selalu menjadi diri sendiri } \\
\text { selama berinteraksi dengan } \\
\text { orang-orang di lingkungan } \\
\text { baru. }\end{array}$ & 42 \\
2 & $\begin{array}{l}\text { Saya mengerti bahasa yang } \\
\text { dipakai oleh orang-orang di } \\
\text { lingkungan baru saya }\end{array}$ & 62 \\
3 & $\begin{array}{l}\text { Memiliki rasa percaya diri } \\
\text { (self confidence) yang } \\
\text { tinggi. }\end{array}$ & 44 \\
4 & $\begin{array}{l}\text { Saya bersifat ekstrovert } \\
\text { (terbuka) dengan orang- } \\
\text { orang di sekitar lingkungan } \\
\text { baru saya }\end{array}$ & 45 \\
5 & $\begin{array}{l}\text { Saya mengetahui yang akan } \\
\text { saya raih di lingkungan } \\
\text { baru saya saat ini }\end{array}$ & 47 \\
6 & $\begin{array}{l}\text { Saya sudah mengetahui } \\
\text { bagaimana budaya di } \\
\text { lingkungan baru saya } \\
\text { sekarang ini (Malang) } \\
\text { Saya selalu bergaul/ ikut } \\
\text { bergabung dengan } \\
\text { himpunan organisasi daerah } \\
\text { saya berasal. }\end{array}$ & 37 \\
\hline 8 & $\begin{array}{l}\text { Saya aktif mengikuti } \\
\text { organisasi kemahasiswaan } \\
\text { (HMJ, BEM atau kegiatan } \\
\text { UKM lainnya) }\end{array}$ \\
\hline Rata-rata \\
\hline
\end{tabular}


(Tinggi)

Tabel 5. Faktor-faktor yang Mempengaruhi Cepat Lambatnya Proses Adaptasi

\begin{tabular}{|c|c|c|}
\hline No & Pernyataan & $\begin{array}{c}\text { Persentase } \\
(\%)\end{array}$ \\
\hline 1 & $\begin{array}{l}\text { Aktif berinteraksi dengan } \\
\text { orang orang lokal/ orang } \\
\text { Malang }\end{array}$ & 42 \\
\hline 2 & $\begin{array}{l}\text { Nyaman dengan adat } \\
\text { istiadat budaya Malang } \\
\text { yang mengutamakan tata } \\
\text { krama }\end{array}$ & 37 \\
\hline 3 & $\begin{array}{l}\text { Saya memiliki kemampuan } \\
\text { kemampuan bersosialisasi } \\
\text { yang tinggi. }\end{array}$ & 46 \\
\hline 4 & $\begin{array}{l}\text { Bersikap terbuka dalam } \\
\text { menghadapi berbagai } \\
\text { masalah di lingkungan } \\
\text { baru. }\end{array}$ & 41 \\
\hline 5 & $\begin{array}{l}\text { Saya senang menghabiskan } \\
\text { waktu bersama teman- } \\
\text { teman baru di lingkungan } \\
\text { saya sekarang. }\end{array}$ & 50 \\
\hline 6 & $\begin{array}{l}\text { Saya berusaha keras } \\
\text { memahami segala sesuatu } \\
\text { di lingkungan baru saya. }\end{array}$ & 34 \\
\hline 7 & $\begin{array}{l}\text { Saya sudah mengenal } \\
\text { bahasa Jawa Malangan } \\
\text { sebelumnya. }\end{array}$ & 67 \\
\hline 8 & $\begin{array}{l}\text { Saya ingin mempelajari } \\
\text { bahasa Jawa } \\
\text { (ngoko,madya,krama) lebih } \\
\text { dalam }\end{array}$ & 46 \\
\hline 9 & $\begin{array}{l}\text { Kurang percaya diri (PD) } \\
\text { memulai pembicaraan } \\
\text { dengan orang baru }\end{array}$ & 59 \\
\hline 10 & $\begin{array}{l}\text { Keinginan untuk selalu } \\
\text { mencari orang yang berasal } \\
\text { dari daerah yang sama. }\end{array}$ & 70 \\
\hline 11 & $\begin{array}{l}\text { Keinginan untuk tidak } \\
\text { mengungkapkan diri terlalu } \\
\text { banyak kepada orang lain. }\end{array}$ & 68 \\
\hline 12 & $\begin{array}{l}\text { Pasif bertukar informasi } \\
\text { yang berkaitan dengan } \\
\text { budaya (budaya asal } \\
\text { dengan budaya baru) }\end{array}$ & 73 \\
\hline 13 & $\begin{array}{l}\text { Saya merasa tidak nyaman } \\
\text { dengan hari-hari saya } \\
\text { ketika berinteraksi sosial }\end{array}$ & 52 \\
\hline 14 & $\begin{array}{l}\text { Saya merasa cemas dan } \\
\text { canggung ketika bertemu } \\
\text { dengan orang-orang lokal } \\
\text { (orang Malang) }\end{array}$ & 55 \\
\hline
\end{tabular}

15 Saya merasa bingung dan takut berinteraksi ketika beradaptasi dengan lingkungan baru

16 Saya merasa canggung berkomunikasi menggunakan Bahasa Jawa dalam keseharian saya di lingkungan baru

17 Saya merasa kurang percaya diri dan kurang bebas mengekspresikan diri di lingkungan baru ini

18 Saya tidak memiliki sense of belonging (rasa memiliki) terhadap lingkungan baru saya

\begin{tabular}{cc}
\hline Rata-rata & $\mathbf{5 4}$ \\
& (Tinggi) \\
\hline
\end{tabular}

Seseorang yang pergi ke suatu tempat baru dan menetap dalam jangka waktu tertentu akan menghadapi tantangan hidup berupa keadaan lingkungan yang baru dan asing. Contohnya adalah mahasiswa dari luar pulau Jawa yang memiliki lingkungan dan budaya yang sangat berbeda kemudian melanjutkan pendidikan di jenjang perguruan tinggi di pulau Jawa. Mahasiswa tersebut akan mengalami perubahan-perubahan yang dapat mengakibatkan culture shock. Culture shock adalah keadaan dimana seseorang mengalami kebingungan terhadap lingkungannya dan menimbulkan emosi negatif (Hutapea, 2014).

Penyesuaian memiliki arti yang sangat luas dan umum digunakan dalam berbagai konteks yang mengandung arti manajemen perilaku dalam kaitannya dengan lingkungan (Chouhan dan Salini, 2006). Masalah utama yang dialami mahasiswa berdasar nilai culture shock dengan kriteria sangat tinggi yaitu aspek sangat ingin pulang ke rumah dan bertemu keluarga dan teman-teman saya di rumah (homesickness) sedangkan upaya untuk mengatasinya yaitu dengan aktif menjalin komunikasi dan berelasi dengan teman-teman baik dari dalam maupun luar kampus.

Penyesuaian diri yang dihadapi oleh mahasiswa perantauan menyangkut aspek akademis dan non-akademis, anatara lain aspek psikologis, seperti rasa rindu ingin pulang (home sick) dan jarak geografis dari keluarga, aspek kultural seperti harus menyesuaikan diri terhadap norma sosial yang baru dan juga interaksi antara dosen dan mahasiswa yang 
berbeda pengalaman orientasi nilai, seperti jarak kekuasaan (power distance), selain itu juga faktor cuaca dan makanan (Hutapea, 2014).

Hal tersebut dilakukan dengan upaya untuk selalu bergaul/ ikut bergabung dengan himpunan organisasi daerah asal. Upaya penyesuaian diri tersebut dipengaruhi oleh banyak faktor yang berperan penting, diantaranya: (1) Kemampuan berbahasa jawa; (2) Tingkat kepercayaan diri dalam memulai berkomunikasi dengan orang lain; (3) Ketergantungan untuk selalu berkumpul dengan teman yang berasal dari daerah yang sama; (4) Keinginan dalam eksistensi diri; (5) Keaktifan bertukar informasi dengan lingkungan baru; (6) Kecemasan dan rasa canggung bertemu dengan orang loka (Malang); (7) Ketakutan dalam berinteraksi dan beradaptasi dengan lingkungan baru; (8) Rasa memiliki lingkungan yang baru.

Banyak orang belum menyadari bahwa budaya dapat mengatur dan membentuk kepribadian dan perilakunya. Hal tersebut baru disadari ketika seseorang pergi ke suatu tempat baru yang memiliki budaya yang berbeda. Seseorang yang masuk ke suatu budaya yang berbeda akan merasakan keterkejutan. Kondisi inilah yang akan menyebabkan sebagian orang gangguan mental atau fisik dalam jangka waktu tertentu. Culture shock memiliki enam karakteristik, yaitu.

1. Ketegangan dalam penyesuaian psikologis.

2. Merasakan seolah-olah kehilangan teman, status, peranan sosial, dan posisi personal.

3. Ketakutan akan ditolak oleh kebudayaan baru.

4. Kebingungan dalam peran, nilai, perasaan, dan identitas diri.

5. Keterkejutan dan kecemasan dengan adanya kebudayaan yang berbeda.

6. Ketidakmampuan dalam beradaptasi dengan lingkungan baru (Pyvis dan Chapman, 2005).

Hasil belajar juga merupakan hasil interaksi antara kegiatan belajar dan mengajar (Dimyati dan Mudjiono, 2006). Hasil belajar dipengaruhi oleh dua faktor, yaitu 1) faktor internal, yaitu faktor yang ada dan dimiliki oleh diri individu yang sedang melakukan proses pembelajaran, seperti faktor jasmani dan psikologis dan 2) faktor eksternal, yaitu faktor yang berasal dari lingkungan atau luar individu, seperti faktor keluarga, sekolah, dan masyarakat (Sugihartono dkk, 2007).
Jika dilihat dari perolehan hasil belajar, diketahui bahwa rata-rata IPK mahasiswa baru yaitu 3,05. Hasil uji hipotesis korelasi product moment dengan pengambilan keputusan (berdasarkan probabilitas (sig.2-tailed)).

- Jika probabilitas (sig.2-tailed) >0,05 maka Ho diterima

- Jika probabilitas (sig.2-tailed) <0,05 maka Ho ditolak

Berdasarkan data uji statistik dengan program SPSS versi 16.0 data yang diperoleh dari hasil penelitian yaitu nilai Probabilitas (Sig. 2-tailed) $=0,054$ dengan nilai $\mathrm{r}$ sebesar -0,217 . Dengan demikian terdapat hubungan negatif dengan nilai probablititas $>0,05$ maka Ho diterima, artinya tidak ada hubungan antara culture shock dengan hasil belajar mahasiswa. Berdasarkan hasil uji statistik diperoleh kesimpulan bahwa tidak ada hubungan antara culture shock dengan hasil belajar mahasiswa. Hal tersebut dimungkinkan dikarenakan mahasiswa baru telah melakukan adaptasi dengan lingkungan sekitar dengan baik. Adaptasi yang baik akibat adanya culture shock dipengaruhi oleh adanya kepekaan kultural yang baik juga. Kepekaan kultural merupakan modal yang besar dalam menciptakan toleransi dan rasa pengertian antara mahasiswa perantau dengan budaya masyarakat Malang. Culture shock yang dialami oleh setiap mahasiswa akan berbeda-beda terkait seberapa besar culture shock mempengaruhi hidupnya (Devinta, dkk, 2015). Mahasiswa luar jawa yang menempuh pendidikan di UNITRI melakukan penyesuaian diri untuk mengatasi culture shock dengan cara aktif menjalin komunikasi dan berelasi dengan teman-teman yang berasal dari kampus UNITRI maupun luar kampus. Selain itu juga keikutsertaan dalam berbagai kegiatan organsasi dan juga banyaknya teman-teman yang berasal dari daerah yang sama juga membantu dan mempercepat kemampuan adaptasi.

Culture shock tidak secara langsung mempengaruhi hasil belajar mahasiswa. Hal tersebut dikarenakan capaian pembelajaran di setiap program studi satu dengan yang lain berbeda. Selain itu juga dilihat dengan linearitas jurusan di sekolah menengah atas dengan jurusan yang dipilih ketika kuliah. Pada dasarnya, setiap individu memiliki kemampuan dalam menyesuaikan diri tetapi setiap individu memiliki tingkat kemampuan penyesuaian diri yang berbeda-beda. Hal tersebut dikarenakan proses penyesuaian diri dipengaruhi oleh berbagai macam faktor, diantaranya faktor 
personal, finansial, sosial, dan edukasi (Gajdzik, 2005). Hal tersebut diperkuat oleh penelitian Khawaja dan Dempsey (2007) bahwa stres yang dialami oleh mahasiswa berkaitan dengan isu finansial, akomodasi, akademik, dan juga lingkungan. Akibatnya, stres ini berdampak signifikan terhadap penyesuaian diri mahasiswa (Skowron, 2004). Mahasiswa yang memiliki stres tinggi akan mengalami kesulitan dalam penyesuaian diri, begitu juga sebaliknya (Hutapea, 2014).

Beberapa peneliti mengelompokkan penanggulangan stres menjadi empat katagori, yaitu 1) memutuskan menghadapi target stres secara langsung, 2) menghindari hal-hal atau situasi yang dapat memicu stres, 3) mengurangi dampak stres melalui aktivitas religius, dan 4) memutuskan menerima hidup apa adanya (Baqutayan, 2011). Penyesuaian diri seorang mahasiswa yang merantau di Kota Malang berkaitan erat dengan dengan kemandiriannya, artinya semakin tinggi tingkat kemandirian mahasiswa maka semakin tinggi pula tingkat penyesuaian diri mahasiswa baru yang merantau tersebut (Anggraini, 2013).

Indonesia sangat kaya akan kemajemukan ragam etnik dan budaya pada masyarakatnya. Multikulturalisme berpotensi dalam membangun kekuatan bangsa yang terdiri atas berbagai latar belakang etnis, agama, ras, budaya dan bahasa (Rosyada, 2014). Pendidikan multikultural hendaknya menjunjung tinggi konsep pendidikan untuk semua dan juga memberikan perhatian khusus pada pengembangan sikap toleran, peduli terhadap perbedaan etnik, budaya, dan juga agama.

Satuan pendidikan dalam hal ini perguruan tinggi harus merencanakan proses pembelajaran yang dapat menumbuhkan sikap multikultural di kalangan mahasiswa agar dapat menjadi anggota masyarakat yang demokratis, menghargai HAM, dan keadilan. Selain itu, perguruan tinggi yang berbasis multikultural harus mempersiapkan kurikulum dan desain evaluasi, serta mempersiapkan pengajar yang memiliki persepsi, sikap, dan perilaku multikultural sehingga menjadi bagian yang memberikan kontribusi positif terhadap pembinaan sikap multikultural bagi mahasiswanya yang beragam.

\section{SIMPULAN DAN SARAN}

Berdasarkan hasil pembahasan tersebut diperoleh kesimpulan bahwa tidak ada hubungan antara culture shock dengan hasil belajar mahasiswa. Culture Shock tidak berperan besar terhadap perolehan hasil belajar, hal tersebut dimungkinkan mahasiswa telah melakukan proses adaptasi yang cepat terhadap lingkungan baru. Hal tersebut juga didukung oleh banyaknya teman-teman yang berasal dari daerah yang sama dan juga kegiatan di kampus yang membantu dalam mempercepat adaptasi mahasiswa baru.

\section{UCAPAN TERIMAKASIH}

Ucapan terima kasih disampaikan kepada Direktorat Riset dan Pengabdian Masyarakat, Direktorat Jenderal Penguatan Riset dan Pengembangan, Kementerian Riset, Teknologi, dan Pendidikan Tinggi yang telah memberikan dana penelitian ini.

\section{DAFTAR RUJUKAN}

Anggraini, E.N. 2013. Hubungan antara Kemandirian dengan Penyesuaian Diri pada Mahasiswa Baru yang Merantau di Kota Malang. (Online). (http://psikologi.ub.ac.id/wpcontent/uploads/2013/10/jurnalERINA.pdf), diakses tanggal 25 Mei 2016.

Arifudin, I. 2007. Urgensi Implementasi Pendidikan Multikultural di Sekolah. Jurnal Pemikiran Alternatif Pendidikan, 12(2): 220-233.

Baqutayan, S.M.S. 2011. The Importance of Religious Orientation in Managing Stress. International Journal of Psychological Studies, 3(1): 113-121.

Chouhan, V.L \& Salini, V. 2006. Coping Strategies for Stress and Adjustment among Diabetics. Journal of The IndianAcademy of Applied Psychology, 32(2): 106-111.

Devinta, M., Hidayah, N., dan Hendrastomo, G. 2015. Fenomena Culture Shock (Gegar Budaya) pada Mahasiswa Perantauan di Yogyakarta. Jurnal Pendidikan Sosiologi, 1-15.

Dimyati dan Mudjiono. 2006. Belajar dan Pembelajaran. Jakarta: PT Rineka Cipta.

Gajdzik, P.K. 2005. Relationship between Selfefficiacy Beliefs and Sosio-cultural Adjustment of International Graduate Students and American Graduate 
Students. (Online). (https://baylorir.tdl.org/baylorir/bitstream/handle/2104 /2682/Gajdzik\%2BFinalDissertation.pdf? sequence $=5$ ), diakses tanggal 20 Mei 2016.

Gayatri, B. 2007. Stressfull Life Events and Behavioural Problems Among Pre University Students. (Online). (http://etd.uasd.edu/ft/th9576.pdf), diakses tanggal 20 Mei 2016.

Hutapea, B. 2014. Stres Kehidupan, Religuisitas, dan Penyesuaian Diri Warga Indonesia sebagai Mahasiswa Internasional. Jurnal Makara Hubs-Asia, 18(1): $25-40$.

Khawaja, N.G. \& Dempsey, J. 2008. A Comparison of International and Domestic Tertiary Student in Australia. Australian Journal of Guidence \& Counselling, 18(1): 30-46.

Kholivah, A. 2009. Pengaruh Culture Shock terhadap Hasil belajar Mahasiswa PPKn
Angkatan Tahun 2007 Fakultas Ilmu Pendidikan Universitas Negeri Malang. UM. Skripsi tidak diterbitkan.

Novera, I.A. 2004. Indonesian Postgraduate Students Studying in Australia: An Examination of Their Academic, Sosial and Cultural Experiences. International Education Journal, 5(4): 475-487.

Pyvis, D \& Chapman, A. 2005. Culture Shock and The International Student 'offshore'. Journal of Research in International Education, 4(1): 23-42.

Rosyada, D. 2014. Pendidikan Multikultural di Indonesia: Sebuah Pandangan Konsepsional. Jurnal Sosio Didaktika, 1(1): 1-12.

Skowron, E.A., Wastern, S.R., \& Azen, R. 2004. Differentiation of Self-modian Collage Gives any Adjustment. Journal of Counseling \& Development, 8(2): 62-82.

Sugihartono, dkk. 2007. Psikologi Pendidikan. Yogyakarta: UNY Press. 